\title{
Editorial
}

\section{O jornalismo científico e a clonagem}

\section{The scientific journalism and the cloning}

George Bernard Shaw, por alguns anos, dedicou-se ao jornalismo, como critíco de arte, literatura, música e, curiosamente, também no campo da ciência. Como crítico científico aproveitou, logo, para lançar seu farpão sarcástico sobre o que ele chamou de insignificância científico-filosófica da teoria da Seleção Natural.

Shaw lança às faces serenas dos cientistas a acusação de que, ao final das contas, o que eles conseguem, como escravos do laboratório, é esconder, de todos e até de si próprios, os seus insucessos. Curiosamente, seu longo e sarcástico arrazoado resultava da convicção de que ele próprio era, também, homem da ciência, pois perante a Ciência, com letra maiúscula, dizia ele, todos são iguais pelo pouco saber, oceânica ignorância e hipóteses efêmeras.

A qualidade da obra literária de Shaw e seu estilo emocional e cortante acabaram transformando-se em armas de fácil manejo para propor ou impor, à aceitação do públi$c o$, algumas de suas extravagantes idéias sobre o que é a ciência. Não lhe faltou também audácia para proclamar que os poetas e artistas marcham sempre na vanguarda dos homens de laboratório e, quando esses últimos se salientam, são realmente verdadeiros artistas da ciência...

Sem desrespeitar o extraordinário valor intelectual de George Bernard Shaw, nem sua notável influência no sistema social inglês de seu tempo, temos que considerar que jor- nalista científico ele nunca foi. Como homem de letras, carregado de emocionalidade e com um espírito facilmente arrastável pelo fluxo de seus próprios discursos, monstrou-se decididamente incapaz de aceitar sua profunda ignorância nos campos da ciência. Não há dúvida que foi capaz de erguer-se, com aquela teimosia própria do Irlandês, com torrentes de talento e uma boa dose de propaganda, a culminâncias tais que passou a ser conhecido pelas iniciais de seu nome, G. B. $\mathrm{S}$. Mas quando alguém se iça a tão vertiginosas alturas, não como um verdadeiro jornalista, mas como alguém que se fazia ler pela sua celebridade, se não possui vastas e sólidas reservas de discrição, tende a resvalar no intrometimento. E foi exatamente essa preciosa qualidade frenadora que faltou a $\mathrm{G}$. B. S. quando se intrometeu pelo campo da ciência, onde seus magníficos tropeços deixaram a descoberto sua enorme ignorância.

Passou-se o tempo, mas ainda hoje proliferam exemplos com idênticas características, mas obviamente, menor celebridade, exemplos esses que acabam nos deixando um doloroso desconforto, pelo desencanto de suas opiniões.

Vem isto a propósito do que se tem lido e ouvido a respeito do processo de clonagem, cujas origens já datam de acerca de 40 anos. Foi no ano de 1960 que começaram sendo feitas descobertas fundamentais que faziam já antever todo um novo mundo, de que tanto se fala e escreve nos nossos dias. 
Não estamos nem perto do que alguém possa suspeitar de nosso antagonismo frente ao noticiário falado e escrito, em geral. Não, de modo algum, quando se diz "de um modo geral". Mas, "de modo específico", como é o presente caso, há que ter enorme cuidado, amparado em conhecimentos fundamentais, não técnicos, mas dos princípios básicos em que se apóia a técnica da clonagem. Considerando as implicações de bioética subjacentes e emergentes dessa técnica, é necessário que a comunidade de cidadãos tenha uma opinião válida a respeito e receba portanto informações necessárias, mas corretas. Tais informações não devem carrear quaisquer tipos de regras de conduta, mas, antes, devem expor os dados biológicos, explicar a natureza das questões éticas envolvidas e analisar as diversas soluções possíveis. Colocar, permanentemente, o cidadão a par do quanto o progresso científico vai pondo à sua disposição é obrigatório, não desprezando uma informação paralela a respeito da qual ele deve pensar constantemente: uma coisa é ciência que produz idéias, outra, bem diferente, é tecnologia que produz resultados.

Uma coisa foram os progressos científicos sobre a energia nuclear, outra coisa foi a bomba atômica: os cientistas não têm qualquer responsabilidade na sua produção e no seu uso. Uma coisa são os progressos feitos pela ciência no vasto campo da genética molecular, com vistas a diminuir a frequiência de genes prejudiciais capazes de condicionar a manifestação de doenças de fundo genético, outra coisa, bem diferente, é a clonagem de seres humanos, com vistas ao aprimoramento eugênico de raças. E disto já temos dolorosas lembranças, quando se pensa no trágico e imoral uso da eugenia. Quem vai fazer a escolha da raça que deverá ser mais forte, mais inteligente, mais fraca, menos inteligente? Quem vai fazer a escolha de quem vai ser clonado para tal e tal tipo de função dentro da sociedade? Estamos fazendo meras considerações fantasiosas! Em junho do passado ano, na cidade de Strasburgo, a UNESCO fez realizar uma convenção para regulamentar a técnica de clonagem de diversas espécies, vegetais e animais, incluindo o homem. Com esse último estará definitivamente proibido qualquer tipo de clonagem. Voltando ao processo informativo escrito ou falado, lamentavelmente, nada se disse ou escreveu sobre a reunião da UNESCO, como sobre os esforços que a comunidade de cientistas, juristas e cidadãos, nos Comitês de Bioética, estão fazendo para que as recentes tecnologias de genética molecular venham a ser usadas para o bem e não para o mal. 